\title{
ВОСПРИЯТИЕ ГУМАНИСТИЧЕСКИХ ИДЕЙ ДЕТСКИХ И ПЕДАГОГИЧЕСКИХ КНИГ Я. КОРЧАКА В СОВРЕМЕННОЙ РОССИИ
}

\author{
Perception of Humanistic Ideas of Children and Pedagogical Books \\ of Y. Korchak in Modern Russia
}

Keywords: humanism, pedagogy, child, creativity, adult, teacher

Contact: МГПУ; sysoevaej@mgpu.ru

Гуманизм предполагает такую общественную организацию, в которой основной идеей является благо человека, а интерес к человеку является движущей силой науки и искусства. Гуманизм - это вечная сложная тема, в том числе в педагогике. Она не перестает быть актуальной, ведь человечность, сочувствие и помощь людей друг другу помогают сохранить мир и сделать возможным толерантное общение людей на земле.

Задача настоящей статьи - проанализировать то, как гуманистическое наследие Януша Корчака воспринимается в современной России, чтобы найти идеи для пропаганды гуманизма в среде молодого поколения. Это не случайная и не орнаментальная задача. Идеи великого польского педагога до сих пор актуальны, а их реализация на деле обещает существенное улучшение не только собственно системы образования, но и всего Российского общества, которое нуждается в гуманизации.

Кредо великого педагога, который пропагандировал идеи гуманной педагогики, автора детских книг, талантливого врача Я. Корчака звучит как призыв: «Услышать! Понять! Установить диалог». Авторству великого педагога и гуманиста принадлежит более двадцати книг, и все они пропитаны любовью к детям. С одной стороны, детские книги Я. Корчака воспитывают в ребенке с самого детства идеи любви и уважения к ближнему. С другой - педагогические книги Я. Корчака учат родителей и педагогов внимательно относиться к каждому ребенку с уважением к его личности и вниманием, пониманием его проблем. Ведь только знание жизни ребенка поможет понять мотивы его поведения, что 
вызывает непрекращающийся интерес российских учителей и их учеников к мировоззрению Я. Корчака. И этот интерес не абстрактный: он реализуется в конкретных уроках, где мы можем встретить такие мысли: «Обратимся к эпизоду из фильма Анджея Вайды «Корчак». Подумайте, что отличает Януша Корчака от учительницы, изображенной в данном эпизоде. (Взрослый человек, педагог, возглавляющий Дом сирот, играет с детьми в паровозик)» (Зорина 2019: 843-844).

Современные российские педагоги находят в наследии Я. Корчака не только идеи для отдельных уроков, но и стратегии для организации целого учебного заведения. Студентка Мезенского педагогического колледжа в городе Орел замечает: «В приюте была "Доска для контактов" с детьми, почтовый ящик для переписки воспитанников с воспитателями, стенгазета, совместные заседания, товарищеский суд, для которого Корчак составил воспитательный кодекс» (Пантюхина 2016: 47-48). Очень жаль, что мы в современной России все еще нуждаемся в том, чтобы обучать детей - будущих граждан нашей страны самоуправлению. Но правда состоит в том, что мы очень остро в этом нуждаемся. В нашем воспитании и образовании все еще не изжит патернализм. И молодое поколение будущих педагогов находит в наследии Я. Корчака конкретное руководство к тому, как организовать самоуправление в учебном заведении. Приведенная мысль вполне подтверждается научными произведениями самих молодых педагогов: «Оригинальная система самоуправления, разработанная Я. Корчаком, во многом не утратила своей ценности и в настоящее время. Многие прогрессивные педагоги используют методы и средства, лежащие в основе этой педагогической системы, для развития активности, самодеятельности, самостоятельности детей, создания такого нравственного климата в детском коллективе, который обеспечивает высокую эффективность воспитательной работы» (Архарова 2019: 204). Конечно, между декларативными заявлениями в научных статьях и реальным воплощением идей Я. Корчака должна стоять большая практическая работа, но можно с уверенностью утверждать, что необходимость этой работы в современной России осознана.

И эти же идеи, но в большем масштабе педагогики всей России осмысливают маститые ученые: «Корчак в своих воспитательных учреждениях построил такую модель. Тут действовали реальные органы само= со=управления на основе норм прямой демократии, что как раз и имеет смысл в небольших сообществах (школьные советы, парламенты, суды чести, школьные печатные издания), которые обеспечивают единство свободы личности и демократического уклада» (Демакова 2016: 20-21). Т. е. идея самоуправления для одного учебного 
заведения, реализованная в своей работе Я. Корчаком, становится не только конкретной инструкцией к действию для студента-педагога, но и дает надежду профессору-педагогу на возможность демократизации всей жизни в России путем воспитания индивидуальности человека в самоуправлении коллектива.

Индивидуальный подход очень важен для воспитания. Эту общепризнанную истину современные российские педагоги также черпают в наследии Я. Корчака. «Корчак писал, что для воспитателя "детей вообще" не существует. Каждый ребенок конкретен, что актуализирует необходимость индивидуального подхода. Воспитатель начинает свою работу с изучения ребенка, с наблюдения за его поведением и реакциями, не пренебрегая кажущимися мелочами, стремясь доброжелательно постичь самые сокровенные желания и самые тонкие переживания» (Аникина 2016: 77). Мы воспитываем не винтики общественного механизма, которые должны незаметно выполнять заданные кем-то функции в обществе, а отдельных личностей с уникальными талантами. Цель педагога, по мнению Я. Корчака, - не только сохранить, но и преумножить качества ребенка, чтобы он стал незаменимым гражданином своей страны, который полезен обществу как созидатель, исследователь и творец. Осознание своей творческой ценности, полезности и нужности окрыляет и помогает достигать новых вершин. К этим же ценностям Я. Корчак предлагает обратиться и родителям. И в современной России, и на всем постсоветском пространстве его назидания не только читают, но и пересказывают, пытаясь осмыслить: «Каждая мама с рождения должна быть первым и главным воспитателем своего ребенка, она обязана знать, что в ее ребенке заложено от рождения, а что выработано упорным трудом. И здесь важно помнить, что все достигаемое тренировкой, настоянием, насилием недолговечно, непрочно, потому что обманчиво, по мнению Корчака» (Истомина 2016: 105). Ненасильственный характер воспитания и образования является в современной России общепризнанной целью, и в этом есть следование идеям Я. Корчака, призывавшего воспитывать прежде всего вниманием.

Некоторым детям настолько не хватает внимания, что даже только назвав ребенка по имени, получаешь радужное свечение его глаз. Он готов сделать все, чтобы внимание к его личности продлилось. Так возникает дружба между педагогом и учениками. «В трудах Корчака находят широкое отражение идеи доверия и уважения к детям» (Воронина 2019: 206), - пишет студентка Нижегородского педагогического университета. Хочется надеяться, что, воспринимая эту идею Я. Корчака, молодые российские педагоги поймут, что уважение к ребенку, отношение к нему всерьез, равная со взрослым доля 
внимания - это условие гуманного обучения и воспитания, необходимое в том числе и в России.

Ребенок видит, что взрослый его уважает и ценит, поэтому начинает доверять ему. Ребенок - это полноценный, состоявшийся человек. Но у учителей осуществить подход, основанный на этом убеждении, иногда не получается, потому что детей в классе слишком много, у учителя нет мотивации дружить и узнавать всех детей, к чему призывал Я. Корчак. В современной России эту гуманистическую идею воспринимают как необходимую не только в школе, но и в вузе. Преподаватель и студентка Красноярского медицинского университета сделали необходимость внедрения идей Я. Корчака в высшем образовании предметом своего исследования. «Анализ педагогического наследия Я. Корчака, осмысление его идей и личный опыт воспитания и обучения позволил нам выявить противоречие между потенциалом педагогических идей, высказанных много лет назад Я. Корчаком, и недостаточной их реализованностью в современном образовании и воспитании современной молодежи» (Корнилова: 2019: 87).

В современной России и на уровне конкретных учебных заведений, и на уровне Министерства образования идет поиск инновационных подходов в воспитании детей и их образовании. Одним из источников инноваций биографу Я. Корчака видятся его знаменитые десять заповедей воспитателя: «За короткое время маленький детдом становится единственным в своем роде, с инновационными подходами в области воспитания детей. Именно здесь появятся его знаменитые 10 заповедей о воспитании ребенка» (Сердюк 2016: 20). Таким образом, читая труды Я. Корчака и реализуя его идеи, современные российские ученые находят пути для обновления образования и решения его современных задач. В частности, практическую реализацию уже получило освоение идей Я. Корчака в дополнительном образовании, где самостоятельность ребенка всегда была выше и где требуется организация плодотворной образовательной среды. «Гуманизация воспитательного пространства реализует свои возможности в системе дополнительного образования и УДО (учреждения дополнительного образования - Е. С.) выполняют здесь особую миссию - это умение организовать вокруг себя пространство защищенного детства, где привычное понятие «любовь к детям» наполняется по Корчаку новым, сложным смыслом» (Политова 2018: 55). Можно ожидать, что в ближайшее время мы увидим в России конкретную реализацию гуманистических идей Я. Корчака и в других типах учебных заведений. 
Индивидуальный подход к ребенку может осуществить самый близкий к нему взрослый. И задача учителя, увидевшего, что у ребенка нет этого близкого взрослого, стать ему таким мудрым наставником. Только тот, кому ты нужен, кто тебя любит, может осуществить индивидуальный подход.

В повести-сказке «Король Матиуш Первый» автор как бы ставит эксперимент. У ребенка, который попадает в ситуацию, когда он вынужден управлять государством, пытается сделать мир лучше, сопротивляясь законам взрослого мира, возникает мотивация к учению из-за необходимости. Когда у детей нет мотивации к обучению, будет полезно прочитать это произведение. Эту книгу необходимо читать ребенку вместе со взрослым, она может стать поводом к серьезному разговору, способствующему появлению и повышению мотивации к обучению. У детей должно укрепиться убеждение, что учиться нужно, не потому, чтобы получить оценку или похвалу, а потому, что эти знания и умение их применять понадобятся ему в будущем. Современные российские авторы понимают, с чем связана надежда Я. Корчака на счастье человечества. Российский ученый-педагог пишет: «Мальчик становится королем. Его подданным - взрослым, непонятны и неприятны его указы и решения, направленные на то, чтобы сделать всех счастливыми. Им просто невдомек, что можно вот так, запросто, быть свободными и независимыми хозяевами своей собственной судьбы» (Помелов 2018: 85).

Следует посвятить ребенка не только в добрые идеалы, но и научить сопротивляться злу, что описано в повести-сказке «Король Матиуш Первый».

Как назидание всем ответственным за жизнь других, как пропаганду идеи самопожертвования воспринимают в России самый решительный шаг в жизни Я. Корчака - смертельный шаг в газовую камеру. Журналист и кинокритик Д. Тасбулатова пишет: «С точки зрения обычного здравого смысла, смерть Корчака была не меньшим абсурдом, чем самоубийство врача, у которого пациент умирает от неизлечимой болезни. Но такие, как Корчак, думают другими категориями. Разве мог он остаться жить с тем горьким сознанием, что бросил детей в смертный час? И чего уж там душой кривить, именно он нужен был им, чтобы смягчить страшные мучения предсмертного часа» (Тасбулатова 2019: 1).

Я. Корчак считал педагогику не наукой о ребенке, а наукой о человеке, тем самым выделял ее общечеловеческую и гуманистическую направленность. Ребенок - не будущий человек, детство является полноценным этапом взрослой жизни. Признание равноценности ребенка и взрослого означает признание права 
ребенка быть тем, кем он есть, - право на индивидуальность, право на уважение человеческого достоинства.

Целевая установка в его воспитательной системе состояла в воспитании активности и самостоятельности личности с развитыми гуманистическими качествами.

Идеи Я. Корчака и сегодня являются основополагающими для разработки путей совершенствования, повышения качества образования. Я. Корчак стал настоящим учителем учителей, может быть, именно поэтому его наследие и остается столь актуальным для всех, кто причастен к воспитанию детей: студентов, учеников, родителей, учителей, воспитателей. «Читая Януша Корчака, читатель может глубже понять великого учителя учителей, так как в его педагогических шедеврах открывается удивительный мир детства. Но еще больше откроется перед читателем внутренний мир великого педагога при чтении его последних дневниковых записей, писем, и молитв» (Невская 2017: 189-190).

Проделанный нами анализ литературы показал, что в современной России для культурных, образованных людей: учителей, преподавателей вузов, студентов разных специальностей, ученых, критиков, журналистов идеи Я. Корчака обретают новую актуальность. И главные среди этих идей - идеи гуманистической педагогики, основанные на уважении и любви к ребенку. Реализация гуманистических идей Я. Корчака в практической работе учреждений образования способно помочь вырастить поколение свободно мыслящих, творческих людей, готовых к самоорганизации и самоуправлению. А это послужит благом для всей страны: общество сможет демократизироваться изнутри, что обеспечит людям свободу и счастье.

\section{Summary}

The purpose of this article is to analyze how the humanist legacy of Janusz Korczak is perceived in contemporary Russia, in order to find ideas for promoting humanism among the younger generation. Contemporary Russian teachers find in Korczak's legacy not only ideas for individual lessons, but also strategies for organizing an entire educational institution. Our analysis of literature has shown that in modern Russia the ideas of Janusz Korczak acquire new relevance for cultural and educated people: teachers, professors, students of different specialties, scientists, critics, and journalists. 


\section{Литература}

Аникина, С. Н. Педагогическая система Януша Корчака. In: Клочкова, Л. И. (ed.) Непрерывное педагогическое образование в контексте инновационных проектов общественного развития. Сборник материалов Всероссийской научно-практической конферениии с международным участием, к 25 летию кафедры педагогики и психологии. Москва: ФГАОУ ДПО АПКиППРО, 2016, с. 76-81.

Архарова, Л. И., Мерлина, Д. А. Реализация педагогической системы воспитания Януша Корчака. In: Байкова, Л. А., Мартишина, Н. В. (eds.) Модернизачия образования: проблемь общего, среднего профессионального и высшего образования. Материаль ХХVI Рязанских педагогических чтений. Рязань: РГУ им. С. А. Есенина, 2019, с. 202-205.

Воронина, И. Р. Гуманистические идеи Януша Корчака In: Горохов, А. А. (ed.) Исследование инновационного потенщиала общества и формирование направлений его стратегического развития. Сборник научных статей 9-й Всероссийской научно-практической конференции с международным участием. В 3-х тm. Курск: ЗАО «Университетская книга», 2019, с. $203-$ 206.

Демакова, И. Д. Януш Корчак: приглашение к диалогу. In: коллектив авторов, Гуманизация образовательного пространства. Материальь международной научной конференции. Москва: Перо, 2016, с. 16-24.

Зорина, Е. Д. Конспект занятия по основам педагогического мастерства на материале повести Януша Корчака «когда я снова стану маленьким». Синергия наук. 2019 (36), с. 842-844.

Истомина, Н. С. Великий гуманизм в жизни и педагогическом наследии Януша Корчака «Как любить ребенка». In Клочкова, Л. И. (ed.) Непрерывное педагогическое образование в контексте инновачионных проектов общественного развития. Сборник материалов Всероссийской научнопрактической конференции с международным участием, к 25-летию кафедры педагогики и психологии. Москва: ФГАОУ ДПО АПКиППРО, 2016, c. 104-107.

Корнилова, Ю. А., Сысоева, А. Ю. Право студента на уважение или какие педагогические правила поддерживает современная молодежь? Исследование на примере «правил жизни» Януша Корчака. Международный студенческий вестник. 2019 (1), с. 187-192. 
Невская, С. С. Януш Корчак - учитель учителей. Народное образование. 2017 (1450/1-2), c. 181-190.

Пантюхина, А. А. Януш Корчак: воспитатель человека! Образование и наука без грании: сочиально-гуманитарные науки. 2016 (4), с. 46-48.

Политова, В. В. Идеи Я. Корчака в гуманизации воспитательного пространства учреждения дополнительного образования детей In: Нуруллина, Г. М., Ерофеева, И. В., Усманова, Л. А. (eds.) Профессионализм учителя как условие качества образования сборник научных трудов IV международного форума по педагогическому образованию и региональной конференции ISATT. Казань: Казанский (Приволжский) федеральный университет, 2018, c. $52-55$.

Помелов, В. Б. Героическая жизнь педагога Януша Корчака (к 140-летию со дня рождения). Вопросы педагогики. 2018 (9), с. 84-86.

Сердюк, С. В. Милосердие длинной в жизнь - биография, творчество и педагогический вклад Януша Корчака (часть 2). Actualscience. 2016 (6). c. $22-24$.

Тасбулатова, Д. Сегодня день гибели Януша Корчака - одного из величайших людей ХХ столетия. Новые известия. 2019 (1), с. 1. 